\title{
A LENDA CASTELHANA: LEITURAS DE EL CID
}

Luiz Filipe Alves Guimarães Coelho ${ }^{59}$

Resumo: Rodrigo Diáz de Vivar se destacou no contexto ibérico de Reconquista através de sua habilidade militar e por sua vida permeada de conflitos, inclusive contra seu rei. Como um personagem de grande relevância, o cavaleiro foi, por muitas vezes, reinterpretado no decorrer da História. Embora todas as leituras de El Cid, estejam "maculadas" pelo contexto em que foram produzidas, a tal ponto de se tornar muito difícil uma pesquisa em busca do "verdadeiro" Campeador, cada uma dessas versões do herói transmite informações indispensáveis sobre o seu próprio tempo. Assim, a produção histórica ganha um novo caráter: o de "passar o exemplo".

Palavras Chave: El Cid, Castela Medieval, Representação de Herói

Através da ligação entre a Literatura e a História nasce uma variedade incrível de mitos, lendas e interpretações idealizadas. Ora, este é o caso de um dos maiores heróis da cultura Ibérica: Rodrigo Diáz de Vivar, o El Cid. A própria palavra "herói" já evidencia o cavaleiro medieval que através de sua perícia militar recebeu o título de El Cid, o qual se tornou alvo de toda uma idealização literária. Sua vida e seus feitos até hoje geram histórias fantásticas que não mostram qualquer compromisso com alguma "verdade histórica". Entretanto, essas interpretações, enquanto afastam e dificultam uma "busca de El Cid", como muitos autores já se aventuraram a empreender, servem muitas vezes para a compreensão dos contextos em que as mesmas foram escritas. É a partir do viés escolhido, dos valores apontados e da escolha de diversos outros fatores pelos autores, que podemos revelar o que estava acontecendo no momento que tais obras foram escritas.

Este artigo tem como objetivo abordar as mais destacadas interpretações do herói, entre as tantas que foram produzidas durante a História. Entre estas, trataremos de fontes de grande importância para a historiografia, como o Poema de Mio Cid, e também de obras mais recentes de historiadores de destaque, Como Menéndez Pídal.

Em 1099 morria o primeiro governante cristão de Valência desde a tomada da cidade pelos mouros (FLETCHER, 2002, p. 13). Este homem, um guerreiro que lutou em diversas batalhas e defendeu várias bandeiras, representaria na memória futura o símbolo da luta entre os cristãos e os islâmicos na Península Ibérica, conhecida como Reconquista. Assim que Rodrigo Diáz faleceu um processo se iniciou: a criação de um mito.

59 Aluno do curso de Graduação em História da Universidade Federal do Paraná. Bolsista do CNPq, orientando da profa. Dra. Fátima Regina Fernandes com a pesquisa Pedro Afonso e o Herói da Reconquista:

El Cid na Crônica Geral de Espanha de 1344. 
Para qualquer historiador que ambiciona pesquisar esse personagem histórico, logo de início se evidencia um grande problęma: as fontes. Na medida em que, se por um lado, quanto mais próximo do tempo de El Cid mais raro é a documentação que poderia oferecer informações, por outro, após a sua morte se observa uma boa quantidade de obras escritas sobre esse herói. Citaremos aqui os principais documentos: o primeiro em que aparece o termo Cid foi um poema em latim escrito em celebração da conquista de Alméria, em 1147. O autor anônimo por duas vezes se refere a Rodrigo Díaz como mio Cidi (FLETCHER, 2002, p. 13). A maneira como o termo é utilizado demonstra que o autor esperava uma pronta identificação por parte do seu público com o personagem ao qual se referia. O termo Cid provém de uma transliteração do árabe sayyid que significa "senhor". Portanto, El Cid equivaleria a "o senhor" ou "o líder". Não há registros que comprovem a utilização deste termo durante a vida de seu portador, porém não é descabido acreditar nesta possibilidade (FLETCHER, 2002, p. 13).

A primeira obra dedicada inteiramente a El Cid se mostra em forma de poesia e se constitui de um manuscrito copiado em Ripoll, por volta do ano 1200. Um dos três poemas contidos no documento é um conjunto de versos em latim, sem título, que se dedicam às primeiras façanhas militares de Rodrigo, mencionando-o diversas vezes como campi doctor (campeador). Foi desta característica que o poema ganhou o título atual de Carmem Campi Doctoris (Canção do Campeador). O período exatamente no qual esta obra foi produzida ainda gera debates na historiografia. Porém, existe certo consenso de que teria sido escrita no monastério de Ripoll, Castela, pouco tempo depois do último acontecimento relatado no poema: a batalha de Almenar que se deu em $1082 .{ }^{60}$

Por outro lado, outra obra escrita pouco tempo depois se mostra mais apreciável: a História Roderici. Esta também recebeu um título moderno, pois, no formato que chegou até nós, encontravase desprovida de um. Estava apenas escrito em seu cabeçalho "Aqui começam os feitos de Rodrigo, o Campeador" (FLETCHER, 2002, p. 124). Este texto trata da vida de Rodrigo até a sua morte. Porém, é depois do primeiro exílio do El Cid que o escritor demonstra um grau de detalhe consideravelmente maior do que nos capítulos anteriores. Sua data de composição é uma grande dúvida, pois o manuscrito que chegou até os nossos tempos é uma cópia datada aproximadamente do ano 1230.

Entretanto, para Fletcher o documento original poderia ser datado entre os 20 anos seguintes à morte de El Cid por dois motivos: o primeiro provém de uma análise de grafia, "no patronímico 'Sánchez' (filho de Sancho) no capítulo 23 do manuscrito mais antigo, a letra 'a' foi substituída pela letra ' $u$ '. Durante a passagem do século XI para o século XII a escrita tradicional castelhana foi sendo modificada, passando da escrita visigótica para a escrita que ficou conhecida como francesa. Uma das diferenças entre as duas escritas se encontrava na primeira letra do alfabeto: na escrita visigótica o "a" não era fechado na parte de cima, o que poderia causar a impressão de "u". É nesse erro de cópia que podemos supor, segundo Fletcher, que o autor original da obra tenha usado a forma escrita visigótica, o que causou uma falha na tradução muitos anos depois quando o responsável pela cópia 60 A obra trata dos momentos anteriores à batalha, onde encontramos Rodrigo se preparando para o combate. Entretanto o poema é interrompido nesta parte e algo entre 10 estrofes foram apagadas, ou de forma deliberada ou pelo próprio tempo, o que poderia levar à conclusões diferentes. (FLETCHER, 2002, pp. 123). 
não devia estar acostumado com a escrita visigótica. Sendo assim, a obra teria sido produzida entre o final do século XI e os primeiros anos do século XII (FLETCHER, 2002, p. 127). A segunda razão, que leva o historiador a crer na proximidade da obra com o tempo em vida do seu objeto, é mais simples: segundo o pesquisador, a relação entre a narrativa e o que pode ser comprovado com outros documentos é tão precisa que o autor deveria estar vivo durante os acontecimentos para tê+los de maneira tão vívidos em sua memória (FLETCHER, 2002, p. 127).

Há, ainda, outro texto relevante sobre Rodrigo Diáz de Vivar, considerada a primeira grande obra redigida em língua castelhana. Nenhum outro documento sobre El Cid recebeu tanto prestígio e foi alvo de tanto debate quanto o Poema de Mio Cid. Liderados por Ramón Menédez Pídal, um grande filólogo espanhol que dedicou sua vida às questões "cidianas", um grupo de historiadores defendiam a fundamentação histórica contida no poema, principalmente no que se referia ao exílio de 1081 a 1086, ao nome de membros do séqüito de Rodrigo e o seu relacionamento com o conde de Barcelona. A teoria de Pídal estava baseada na idéia de que tradições orais passadas a cada geração poderiam conter informações históricas corretas. Aliado a isto, Pídal tentava provar que a obra tinha sido escrita por volta de 1140, quarenta e um anos após a morte do Cid. Algumas pesquisas, analisando o modo de escrita e algumas referências a procedimentos judiciais e burocráticos contidos no documento, sugeriram que a obra fosse datada por volta de 1175 (FLETCHER, 2002, p. 254).

Reinhardt Dozy, um pesquisador holandês que havia descoberto textos árabes que tratavam de El Cid, foi pelo caminho contrário das interpretações tradicionais: se baseou na visão do "inimigo". Julgando o poema como "ficção e vazio de qualquer valor como testemunho histórico", Dozy caracterizoủ Rodrigo como um homem rude, um mercenário interessado apenas em seu enriquecimento e disposto a fazer o necessário para tal, e, o mais importante, "mais muçulmano que católico" (FLETCHER, 2002, pp. 263).

Já Fletcher utiliza três características para mostrar o herói do Poema de Mio Cidi como sendo apenas fruto de uma produção literária sem grande profundidade histórica: em primeiro lugar o fato de Rodrigo ser enfaticamente castelhano. Durante a primeira parte da obra observamos que, acima de tudo, Rodrigo sente a perda de "sua terra natal" (FLETCHER, 2002, pp. 254). Jordi Pardo Pastor, em seu texto A Representação do Cavaleiro na Épica Espanhola: o Cid Campeador um Canto de Fronteira, corrobora essa idéia: "A pátria é o que de mais grandioso existe para o Cid. Tudo o que nela se encontra é profundamente amado por nosso herói, os palácios, as casas, a gente, e mais importante sua família" (PASTOR, 2003). Contudo, esse tipo de relação patriótica com a terra natal é algo totạlmente anacrônico se for atribuído a um cavaleiro medieval. Principalmente quando este cavaleiro em questão lutou em algumas batalhas ao lado dos muçulmanos, inclusive contra os seus antigos aliados cristãos, algo que o Poema nem menciona.

Esse ponto leva à segunda crítica que Fletcher faz ao documento: El Cid é mostrado como um cristão fervoroso. Mais do que um cristão comum, o Poema mostra o cavaleiro "rezando, invocando São Tiago, recebendo a graça de uma visão do Arcanjo Gabriel, desejando recuperar Valência para a 
cristandade" (FLETCHER, 2002, pp. 255). As poucas vezes que o Poema menciona as várias alianças temporárias que Rodrigo fez com os muçulmanos, estas são retratadas como meras estratégias para manipular seus tributários contra outros infiéis.

Por último, a sua maneira sempre leal ao rei, mesmo que o herói fosse vítima de injustiça desse senhor, demonstra outra discrepância com o cavaleiro retratado pelas fontes. O Cid histórico nã̀o poderia ser mais diferente que este: o cavaleiro representa na verdade insubordinação para com seu rei (FLETCHER, 2002, pp. 256). O primeiro exílio de Rodrigo simboliza sua personalidade independente: após um ataque e saque feito ao castelo de Gormaz por bandidos vindos das regiões de Toledo, El Cid organiza suas hostes e, sem esperar por ordens reais, invade o reino muçulmano, saqueando e devastando suas terras. Uma das razões que podem ter levado o cavaleiro a tal impetuosidade, era seu possivel interesse em saquear e/ou tomar aquelas terras que se localizavam próximas as suas. De qualquer modo, tal insubordinação mostra como Rodrigo agia por conta própria, sem se preocupar com a autorização de seu governante, que, aliás, há anos lutava para assegurar a manutenção do governador de Toledo, seu protegido. ((FLETCHER, 2002, pp. 178-179).

Para ajudar a compreender o Poema de Mio Cid vale à pena levar em conta o que se passava na Península Ibérica durante o período: uma nova seita de caráter beligerante crescia entre os muçulmanos, os almôadas. Em 1173, esta seita já controlava a totalidade do al-Andaluz. Os domínios castelhanos se viam novamente divididos e, com a morte de Sancho III, ficou apenas seu filho, Afonso VIII, um bebê, para reinar. As disputas pela regência só tiveram fim com a maioridade do rei em 1169. Entretanto, a ameaça almôada crescia cada vez mais e, em 1195, os castelhanos amargam uma derrota decisiva contra os muçulmanos na batalha de Alarcos. Apenas em 1212, Afonso VIII conseguiria conter o avanço dos muçulmanos.

Não é necessária demasiada análise para perceber a relação entre o herói do Poema de Mio Cid e os problemas da época. Castela estava sendo novamente ameaçada por um inimigo árabe (os almôadas) e pelos conflitos internos dos que colocavam seus interesses acima das necessidades do reino, esquecendo seu dever para com o rei e o reino. Era preciso um herói que mostrasse aos nobres como eles deveriam agir. $\mathrm{O}$ autor misterioso da obra provavelmente queria mostrar um grande cavaleiro, habilidoso no campo de batalha como nenhum outro, nobre de coração, fiel ao rei e temente a Deus, que, agindo por esses princípios alcançou grande prestígio e riqueza (FLETCHER, 2002, pp. 257).

José Rivair Macedo em seu texto Mouros e Cristãos: A Ritualização da Conquista no Velho e no Novo Mundo comenta a utilização do Cantar (Poema) de Mio Cidi para divulgar imagens e valores relacionados à cristandade e na transformação do Cid como um exemplo a ser copiado (RIVAIR, 2000). $\mathrm{O}$ texto de Jordi Pastor vai pelo mesmo caminho: a idéia que o pesquisador defende é a de que o Poema tinha sido escrito por um habitante da fronteira para a fronteira. Dessa maneira, o personagem mitificado de El Cid serviria para arrebatar as pessoas em um romance envolvente e, ao mesmo tempo, didático, gerando um exemplo a ser seguido. Pastor conclui dizendo que o El Cid encontrado 
no documento deveria ser enxergado como "a esperança da sociedade da época" (PASTOR, 2003).

O próprio Pídal, o maior defensor do Poema de Mio Cidi, mostra-se vulnerável ao mesmo tipo de análise contextual que utilizamos para abordar a sua fonte mais querida: Ramón Menéndez Pídal nasceu em Corunna em 1869 de país de origem asturiana. Foi seu tio, o marquês de Pídal, colecionador de gosto erudito, que lhe apresentou o personagem histórico El Cid, O marquês havia comprado o único manuscrito do Poema de Mio Cid. E assim, ainda pequeno, Pídal iniciava uma relação que duraria por toda a sua vida. Entretanto, foi durante sua lua-de-mel que o pesquisador vivenciou um momento que marcaria sua forma de ler documentos e fontes: ele "e sua mulher ouviram uma lavadeira as margens de um rio cantar uma balada, até então sem registro, sobre a morte do filho mais velho de Fernando e Isabel, ocorrida quase quatrocentos anos antes. Eles reconheceram nela informações históricas autênticas" (FLETCHER, 2002, pp. 265), informações estas que se presumia estarem além do conhecimento de uma simples lavadeira.

O tratamento dado por Dozy ao Cid gerou uma revolta em Pídal, o qual anos mais tarde o acusaria de "cidofobia". Em sua La España del Cid, Píidal critica a tese do historiador holandês, acusando-o de se deixar "desencaminhar pelo racionalismo". Esta crítica demonstra a influência de outro escritor espanhol: Marcelino Menéndez y Pelayo, um defensor ferrenho da idéia de Espanha como a defensora da Fé Católica.

A última década do século XIX foi de anos de humilhação para a Espanha, a decadência econômica e a perda de territórios em derrotas vergonhosas para os Estados Unidos faziam com que os historiadores olhassem para trás para tentar entender "onde erraram". Foi nesse contexto de humilhação internacional e saudosismo que Pídal produz seu texto. Observamos com grande clareza em seu livro a tentativa de construção de uma identidade espanhola fundada em valores castelhanos. É uma tentativa do pesquisador de levantar a moral de seu país através de heróis do passado. No próprio prefácio da primeira edição de La España del Cid, assim como na conclusão, Pídal admite que sua obra tinha também um caráter didático. “Menéndez Pídal tinha lições a ensinar à sua geração, talvez de forma muito semelhante ao autor do Poema de mio Cid, que tinha lições - bastante semelhante, por sinal - a ensinar para a versão de Pídal” (FLETCHER, 2002, pp. 264).

Através dessa breve análise das interpretações sobre a personagem El Cid, algumas idéias podem ser delineadas. Por mais insubordinado, cruel ou mesquinho que um herói possa ter sido em vida, ele sempre será lembrado como um herói. Mesmo entre os primeiros documentos que falam do Cid, observa-se, da parte dos autores, certa admiração - com exceção dos autores muçulmanos, por razões óbvias. Entretanto, conforme o tempo vai passando e o mito vai se espalhando e se desenvolvendo, as interpretações sobre o personagem histórico vão se tornando cada vez mais míticas. Esse mesmo cavaleiro que lutava para si, que era tão justo, ou tão cruel, quanto qualquer putro guerreiro de sua época, séculos após sua morte viraria símbolo de uma pretensa "espanidade" apenas por ter sido um excelente guerreiro e estrategista.

Além desse caráter santo que podemos notar em alguns processos de mitificação de 
personagens históricos, devemos observar outro lado, o lado do exemplo: como os heróis são usados para ensinar. É exatamente em tempos difíceis que os homens mais buscam heróis a quem se espelhar. O próprio Pídal demonstra isso: seu El Cid, assim como o El Cid do Poema de mio Cid, são mais do que meramente pessoas de tempos passados, eles são professores exemplos de nobreza, ou de conduta. Eles servem para ensinar e para guiar as pessoas. Assim, a escrita histórica deixa de ter um papel apenas narrativo, ela serve para lembrar as pessoas da grandeza passada, seja ela a grandeza de um homem ou a grandeza de seu próprio país. Podemos afirmar que esse caráter didático dos escritos sobre um personagem seja o responsável por iniciar os processos de mitificação do mesmo: quanto mais despido de falhas demonstra ser, melhor é a lição que ele tem para dar.

\section{REFERÊNCIAS}

FLETCHER, R. Em busca de El Cid. São Paulo: Unesp. 2002

MENDÉNDEZ PÍDAL, Ramón. La Espana del Cid, Madrid: Espasa-Calpe. 1950

Cantar de Mio Cid: texto gramática y vocabulario. Madrid: Espasa-Calpe. 1980

El Cid Campeador. Buenos Aires: Espasa-Calpe, 1947

PASTOR, Jordi P. A Representação do Cavaleiro na épica Espanhola: o Cid Campeador, um Cante de Fronteira. http: IIwww.hottopos.com\rih8Vjordi.htm. Acessado no dia 30/07/2007

RIVAIR, José Macedo. Mouros e Cristãos: A Ritualização da Conquista no Velho e no Novo Mundo. http:// paginas.terra.com.br/arte/gtmedieval/mouros_e_cristaos.pdf. Acessado no dia 31/07/2007

MEDEIROS, Décio Martins. El Cid Campeador. Rodrigo Díaz de Vivar, Um Estudo de Cronologia e Genealogia. http://www.geocities.com/demedeir/ElCid.html. Acessado em 31/07/2007

ALMEIDA, Maria do S. Poema de Mio Cid. Rio de Janeiro: Francisco Alves. 1988

HORRENT, Jules. Historia y poesía em torno al "Cantar de Mio Cid”. Barcelona: Ariel, 1973 